\title{
The Crime of Aggression and Humanitarian Intervention on Behalf of Women
}

Beth Van Schaack

SantaClara University, bvanschaack@scu.edu

Follow this and additional works at: http://digitalcommons.law.scu.edu/facpubs

Part of the Law Commons

\section{Automated Citation}

Beth Van Schaack, The Crime of Aggression and Humanitarian Intervention on Behalf of Women (2011), Available at: http://digitalcommons.law.scu.edu/facpubs/615

This Article is brought to you for free and open access by the Faculty Scholarship at Santa Clara Law Digital Commons. It has been accepted for inclusion in Faculty Publications by an authorized administrator of Santa Clara Law Digital Commons. For more information, please contact sculawlibrarian@gmail.com. 


\title{
The Crime of Aggression and Humanitarian Intervention on Behalf of Women
}

\begin{abstract}
This article is part of a larger project to analyse the rarely-considered gender aspects of the crime of aggression and to explore whether or not the amendments adding the crime of aggression to the Statute of the International Criminal Court (ICC) represent an advancement for women. This piece focuses on the potential for the new provisions to chill bona fide exercises of humanitarian intervention given that (1) the crime is expansively drafted to potentially cover all uses of sovereign force, (2) delegates rejected efforts by the United States to include an express exception for military operations launched to prevent the commission of other crimes within the jurisdiction of the ICC, and (3) other proposals that would have prevented humanitarian interventions from being considered 'acts of aggression' were not fully explored or implemented. The article acknowledges that feminist theory may never fully come to terms with a notion of humanitarian intervention given the doctrine's valorisation of militarism, especially in light of the fact that women are so often excluded from decisions about uses of force. It nonetheless argues that if we want to hold out the possibility of humanitarian intervention being deployed in defence of women, elements of the new provisions (such as the terms 'manifest', 'character', 'gravity', and 'consequences') should be interpreted to exclude situations involving the nascent responsibility to protect doctrine.
\end{abstract}

Keywords

international criminal law; International Criminal Court (ICC); women; crime of aggression; national sovereignty; humanitarian intervention; just war

\section{Introduction}

Any feminist defence of the doctrine of humanitarian intervention must take as 26 its starting point the recognition that the substantial denial of women's rights whether civil, political, economic, social, or cultural - has never served as the

\footnotetext{
*) The author served as the Academic Advisor to the U.S. delegation for the ICC Review Conference in Kampala, Uganda. The views expressed herein are her own. The author is grateful for the feedback of all the participants in the Conference on Women and International Criminal Law cohosted by IntLawGrrls and the American Society of International Law and especially the generous comments of Diane Marie Amann, Margaret deGuzman, and Jaya Ramji-Nogales.
} 
sole or primary basis for military intervention. ${ }^{1}$ Advocating the deployment of humanitarian intervention on behalf of women requires an acceptance of the legitimacy, if not lawfulness, of the use of armed force without Security Council approval. ${ }^{2}$ This, in turn, requires a coming to terms with a certain valorisation of militarism and its inherent masculinities - a perspective that is alien to much feminist thinking. Nonetheless, while women remain under the threat of mass violence, we should not foreclose ongoing efforts to develop a workable doctrine of humanitarian intervention to prevent the commission of grave crimes that are subject to prosecution before the International Criminal Court (ICC) in the event of Security Council political paralysis or inaction.

If we hold out the possibility that humanitarian intervention might someday be deployed to protect women from the ravages of war and gender-based violence, we should be concerned about the threat of over-deterrence posed by the new provisions on the crime of aggression ${ }^{3}$ recently added to the ICC Statute. ${ }^{4}$ The crime of aggression is expansively drafted in a way that implicates all uses of force that might be construed to constitute a 'manifest' violation of the U.N. Charter. Whereas the concept of self-defence has a Charter basis ${ }^{5}$ and is relatively well established under international law, the right to use force in defence of others is more contested. As a result, the codification of the crime of aggression and the eventual threat of prosecution may chill those uses of force that are protective in nature, such as interventions pursuant to the nascent doctrine of responsibility to

1) See Christine Chinkin, 'A Gendered Perspective to the International Use of Force', 12 Australian Year Book of International Law (1988-89) 290 ("Oppression and acts of brutality towards women have never been regarded in the same light as slavery, genocide and apartheid"); see also ibid., p. 291 ("The invisibility of women in any legal justifications for the use of force is striking.").

2) See Independent International Commission on Kosovo, The Kosovo Report: Conflict, International Response, Lessons Learned (Oxford University press, Oxford, 2000) p. 4, <www.reliefweb.int/library/ documents/thekosovoreport.htm>, 17 February 2011 ("The Commission concludes that the NATO military intervention was illegal, but legitimate.").

3) This article is part of a larger project to analyse the rarely-considered gender aspects of the crime of aggression and to explore whether or not the amendments to the ICC Statute represent an advancement for women. See also Beth Van Schaack, 'The Grass That Gets Trampled When Elephants Fight: Will the Codification of the Crime of Aggression Protect Women?', 15 UCLA Journal of International Law \& Foreign Affairs (2011) _ (forthcoming).

4) Rome Statute of the International Criminal Court, Art. 36(8), 1 July 2002, 2187 U.N.T.S. 90 [hereinafter ICC Statute]. The aggression amendments, which will not take effect until completion of a ratification process, are the result of a Review Conference held in 2010 in Kampala, Uganda. For a discussion of the negotiations surrounding the crime of aggression, see the IntLawGrrls series on aggression, <intlawgrrls.blogspot.com/search/label/Crime\%20of\%20aggression\%20series>, and the Kampala Conference, <intlawgrrls.blogspot.com/search/label/Kampala\%20ICC\%20 series>. See also Beth Van Schaack, 'Negotiating at the Interface of Power \& Law: The Crime of Aggression', 49 Colorado Journal of Transnational Law (2011) _ (forthcoming), available at $<$ papers.ssrn.com/sol3/papers.cfm?abstract_id=1668661>.

5) U.N. Charter, Art. 51. 
protect. ${ }^{6}$ Such uses of force do not directly implicate sovereign prerogatives in the way that other uses of force of questionable legality - such as acts of pre-emptive/ preventative self-defence or military responses to acts of terrorism - might. For this reason, humanitarian uses of force may be more susceptible to processes of deterrence. The potential for over-deterrence should be a concern for those of us working to enhance the ability of international law to improve women's lives and protect them from abuse.

With the drafting process behind us, whether or not the Court will hear aggression cases involving humanitarian interventions now depends on the attitudes of members of the Assembly of States Parties and the Security Council - which are empowered to refer situations to the Court - as well as the discretion of the Prosecutor. During the aggression negotiations, the United States delegation endeavoured to create a space in the definition of aggression to argue the legality of bona fide humanitarian interventions. ${ }^{7}$ The most pointed proposals of the United States were ultimately not implemented. There is language, however, in the final resolution adopting the aggression amendments that should be interpreted by these actors to exempt bona fide humanitarian interventions from prosecution as the crime of aggression.

6) See International Commission on Intervention and State Sovereignty (ICISS), The Responsibility to Protect (International Development Research Centre, Ottawa, 2001) p. 69 (explaining that "the responsibility to protect its people from killing and other grave harm was the most basic and fundamental of all the responsibilities that sovereignty imposes-and that if a state cannot or will not protect its people from such harm, then coercive intervention for human protection purposes, including ultimately military intervention, by others in the international community may be warranted in extreme cases".); 2005 World Summit Outcome, U.N. General Assembly Resolution 60/1 (U.N. Doc. A/RES/60/1) para. 138, (24 October 2005); U.N. Security Council Resolution 1674 (U.N. Doc. S/RES/1674) para. 4, (28 April 2006) (containing a reaffirmation by the Security Council that "the provisions of paragraphs 138 and 139 of the 2005 World Summit Outcome Document regarding the responsibility to protect populations from genocide, war crimes, ethnic cleansing and crimes against humanity."). But see Chair of the High-Level Panel on Threats, Challenges \& Change, Transmittal Letter from the Chair of the High-Level Panel on Threats, Challenges and Change addressed to the Secretary-General (U.N. Doc. A/59/565) para. 203, (2 December 2004) (envisioning the responsibility to protect doctrine as limited to action by the Security Council).

7) This position reflected themes from President Obama's Nobel acceptance speech:

More and more, we all confront difficult questions about how to prevent the slaughter of civilians by their own government, or to stop a civil war whose violence and suffering can engulf an entire region. I believe that force can be justified on humanitarian grounds, as it was in the Balkans, or in other places that have been scarred by war. Inaction tears at our conscience and can lead to more costly intervention later.

See Barack H. Obama, Nobel Lecture by Barack H. Obama: A Just and Lasting Peace, 10 December $2009,<$ nobelprize.org/nobel_prizes/peace/laureates/2009/obama-lecture_en.html>. 


\section{Deconstructing the Crime of Aggression}

References to sex and gender pervade the Statute of the International Criminal Court (ICC), not only in its substantive law, but also in its structures and procedures. In particular, the ICC Statute contains an expansive list of gender crimes in the war crimes and crimes against humanity provisions. ${ }^{8}$ Persecution on the basis of gender - along with ethnicity or race - is penalized. ${ }^{9}$ The definition of genocide in Article 6 mirrors that of the Genocide Convention, but the Elements of Crimes - drafted to assist the ICC in interpreting its substantive offenses - note that "serious bodily or mental harm" "may include, but is not necessarily restricted to, acts of torture, rape, sexual violence or inhuman or degrading treatment" ${ }^{10}$ In terms of personnel, the ICC Statute requires states parties to choose judges and other staff with experience with "violence against women or children"11 and calls for "fair representation of female and male judges". ${ }^{12}$ The ICC Statute also contains a non-discrimination provision stating that the ICC's application and interpretation of the law must be consistent with internationally recognised human rights and be without adverse distinction founded on, inter alia, gender. ${ }^{13}$

These provisions in the ICC Statute are the result of the intense and coordinated advocacy work of a coalition of women's groups, then called the Women's Caucus for Gender Justice, which was active during the drafting of the ICC Statute..$^{14}$ To achieve these provisions, the Caucus had to overcome significant resistance from a handful of states and non-governmental delegations - including the Holy See, several anti-choice organizations, and a core of Islamic states - that were less sympathetic to the imperative of gender justice. ${ }^{15}$ Though gender played

8) Articles 8(2)(b)(xxii) and 8(2)(e)(vi) of the ICC Statute specifically designate the crimes of rape, sexual slavery, enforced prostitution, forced pregnancy, enforced sterilisation, and other forms of sexual violence as war crimes whether committed in international or non-international armed conflict. The same crimes are listed as crimes against humanity. ICC Statute, supra note 4, Art. 7(1)(g). Enslavement as a crime against humanity is also defined with reference to the trafficking of women and children. Ibid., Art. 7(2)(c).

9) Ibid., Art. 7(1)(h).

10) International Criminal Court, Elements of Crimes (U.N. Doc. PCNICC/2000/1/Add.2) p. 2, n.3 (2000).

11) ICC Statute, supra note 4, Arts. 36(8)(b) (Judges), 42(9) (Office of the Prosecution), and 43(6) (Victims and Witnesses Unit).

12) Ibid., Art. 36(8)(a)(iii).

13) Ibid., Art. 21(3).

14) For a discussion of the contributions of the Caucus and other feminist organisations, see Barbara Bedont and Katherine Hall-Martinez, 'Ending Impunity for Gender Crimes under the International Criminal Court', 6 Brown Journal of World Affairs (1999) 65. The Caucus, reorganised in 2004 as the Women's Initiatives for Gender Justice, is now focused on monitoring the Court's implementation of the gender provisions of the ICC Statute and channeling the concerns of women in the regions in which the ICC is working. See <www.iccwomen.org/>.

15) See Janet Halley, 'Rape at Rome: Feminist Interventions in the Criminalization of Sex-Related Violence in Positive International Criminal Law', 30 Michigan Journal of International Law (2008) 
a central role in the negotiations surrounding other aspects of the ICC Statute, there was no mention of gender in the recent negotiations to add the crime of aggression to the ICC Statute and little involvement by non-governmental organisations focused on advancing the interests of women worldwide. Instead, the negotiations were dominated by states with sovereign agendas as varied as alternatively preserving or eroding the power of the Security Council in international relations. ${ }^{16}$

As a result of the recently-concluded negotiations, the crime of aggression has been defined as follows:

Article 8 bis

Crime of aggression

1. For the purpose of this Statute, "crime of aggression" means the planning, preparation, initiation or execution, by a person in a position effectively to exercise control over or to direct the political or military action of a State, of an act of aggression which, by its character, gravity and scale, constitutes a manifest violation of the Charter of the United Nations.

2. For the purpose of paragraph 1, "act of aggression" means the use of armed force by a State against the sovereignty, territorial integrity or political independence of another State, or in any other manner inconsistent with the Charter of the United Nations. Any of the following acts, regardless of a declaration of war, shall, in accordance with United Nations General Assembly resolution 3314 (XXIX) of 14 December 1974, qualify as an act of aggression. ${ }^{17}$

The definition then provides a list of "acts of aggression" (such as invasion, bombardment etc.) drawn verbatim from Article 3 of General Assembly Resolution 3314, the instrument that was meant to guide the Security Council in exercising its U.N. Charter-based duties to respond to breaches of the peace and acts of aggression. The amendments thus define two phenomena - a crime of aggression, set out in subsection 1 of the Article, and an act of aggression, set out in subsection 2. These two inquiries will generally be considered in reverse order such that the act of aggression committed by a state serves as a predicate for the prosecution of an individual for the crime of aggression. Thus, an individual will be held liable for the crime of aggression only when he or she plans, prepares, initiates, or executes one or more acts of aggression through the machinery of a state. Only those acts of aggression that by their "character, gravity and scale" constitute

\footnotetext{
1 (discussing role of activists in negotiations to ensure the ability to prosecute sex crimes within the statutes of the international criminal law tribunals).

16) See Beth Van Schaack, 'Negotiating at the Interface of Power \& Law: The Crime of Aggression', 49 Columbia Journal of Transnational Law (2011) _ (forthcoming) (discussing the negotiating dynamics at the Kampala Review Conference where the amendments were adopted).

17) Rev. Conf. of the Rome Statute, 13th plenary meeting (I.C.C. Doc. RC/Res. 6) (advance version) (11 June 2010), <www.icc-cpi.int/iccdocs/asp_docs/Resolutions/RC-Res.6-ENG.pdf> [hereinafter Resolution RC/Res.6].
} 
a "manifest violation" of the Charter, viewed objectively, can give rise to the crime of aggression.

Needless to say, it would be a singular achievement if the codification and prosecution of the crime of aggression were able to reduce the incidence of conflict in the world and give real content to the 'right to peace' that would improve the lives of so many women. ${ }^{18}$ And yet, there is a risk that codification of the crime of aggression may result in more ex post prosecutions of leaders launching aggressive campaigns at the expense of ex ante efforts to halt threatened or ongoing violence. ${ }^{19} \mathrm{~A}$ number of elements of the aggression amendments implicate the concept of humanitarian intervention - a fact not lost on delegates during the negotiations. Delegates could have framed the definition to more expressly leave open a space for exempting humanitarian intervention from prosecution. But very few such proposals were seriously considered, let alone adopted. Most importantly, delegates rebuffed several efforts by the United States to explicitly preserve a right to engage in truly humanitarian intervention and instead favoured more implicit language to this effect. The result is that the various organs of the Court will enjoy considerable discretion in dealing with such scenarios. ${ }^{20}$

\section{Exempting Humanitarian Interventions}

Once it began participating in the negotiations in November 2009, the United States took the position that the definition of aggression under consideration was flawed and that the apparent consensus on the elements of the crime masked significant disagreements regarding what types of sovereign conduct could constitute the crime of aggression. By the time of the Kampala Review Conference, it was clear that delegates were loath to reopen negotiations over the definition, especially at the behest of a latecomer. As a result, the U.S. delegation endeavoured to address perceived problems through a series of 'Understandings' to preserve an opening for claims about the legality of humanitarian interventions and

18) See U.N. General Assembly Resolution 33/73, Declaration on the Preparation of Societies for Life in Peace, (U.N. Doc. A/RES/33/73) (Dec. 15, 1978); Philip Alston, 'Peace as a Human Right', in Richard Pierre Claude and Burns H. Weston (eds.), Human Rights in the World Community, (1980) p. 198.

19) Kenneth Anderson, 'The Rise of International Criminal Law: Intended and Unintended Consequences', 20 European Journal of International Law (2009) 333 (noting how international criminal law has emerged as an alternative to intervention). The International Criminal Tribunal for the Former Yugoslavia, for example, has been criticised for being a consolidation prize in lieu of a more robust military response to atrocities.

20) The early negotiation history is available in Stefan Barriga, et al., The Princeton Process on the Crime of Aggression: Materials of the Special Working Group on the Crime of Aggression, 2003-2009, (Princeton University Press, Princeton, 2009). 
other arguably legitimate, yet potentially unlawful, uses of force. ${ }^{21}$ The ability of 150 the United States to advocate this position was complicated by its central role in 151 orchestrating two military interventions laying claim to the humanitarian man- 152 tle: Kosovo in 1999 and Iraq in 2003.

The United States' effort to make explicit reference to a right of humanitarian intervention in the Understandings failed when delegates rejected the following proposed language:

It is understood that, for purposes of the Statute, an act cannot be considered to be a manifest violation of the United Nations Charter unless it would be objectively evident to any State conducting itself in the matter in accordance with normal practice and in good faith, and thus an act undertaken in connection with an effort to prevent the commission of any of the crimes contained in Articles 6, 7 or 8 of the Statute would not constitute an act of aggression.

As an alternative, the United States sought other interpretive language focused on 162 gravity and purpose to more indirectly preserve the ability of states to engage in humanitarian interventions.

One angle was to tether the definition of aggression more closely to Resolution 3314 , adopted by the General Assembly by consensus in $1974 . .^{22}$ Although supporters of the current definition touted its Resolution 3314 pedigree, the amendments depart from that instrument in subtle yet significant ways. Most importantly, both Resolution 3314 and the U.N. Charter ${ }^{23}$ envision a continuum of unlawful uses of force, only some of which rise to the level of aggression. The ICC definition, by contrast, is susceptible to a reading that every violation of Article 2(4) of the U.N. Charter as well as violations of a state's "sovereignty" is

21) Harold H. Koh, Legal Adviser of the U.S. Department of State, made the following intervention in Kampala:

Although we respect the considerable effort that has gone into the Princeton Process [the intersessional aggression negotiations], we believe that without agreed-upon understandings, the current draft definition remains flawed. We are concerned that the apparent consensus on the wording of Article 8bis masks sharp disagreement on particular points regarding the meaning of that language that must be addressed before the amendments on the crime of aggression can enter into force.

Harold H. Koh, Legal Adviser of the U.S. Department of State Statement at the Review Conference of the International Criminal Court (4 June 2010), <www.state.gov/s/l/releases/remarks/142665 .htm>.

22) U.N. General Assembly Resolution 3314, U.N. GAOR, 29th Sess., Supp. No. 31 (U.N. Doc. A/9631) 142-43 (1974).

23) Article 39 of the U.N. Charter describes three prohibited uses of force: "threat[s] to the peace, breach[es] of the peace, or act[s] of aggression." U.N. Charter, art. 39. 
an "act of aggression". Echoing language from Resolution 3314's preamble, the United States managed to attain a formal Understanding to the effect that "It is understood that aggression is the most serious and dangerous form of the illegal use of force . ... . ${ }^{24}$ In addition, the United States successfully advocated the adoption of an Understanding that reads:

[A] determination whether an act of aggression has been committed requires consideration of all the circumstances of each particular case, including the gravity of the acts concerned and their consequences, in accordance with the Charter of the United Nations.

\subsection{Identifying a "Manifest" Violation of the U.N. Charter}

Only those acts of aggression that constitute a "manifest" violation of the U.N. Charter will give rise to a prosecution for the crime of aggression. The term "manifest" in Article 8(1), which was never defined, emerged as a compromise term that bridged the positions of two sets of delegates. One camp wanted no threshold at all. This position was premised on the theory either that every act of aggression should be subject to prosecution, or that only "the most serious crimes of international concern" would be prosecuted before the ICC. ${ }^{25}$ In the other camp were delegates that sought a higher threshold to limit prosecutions to "flagrant" breaches of the U.N. Charter, wars of aggression, "unlawful" uses of force, or acts of aggression geared toward occupying or annexing territory. Any one of these qualifiers - with the exception perhaps of "flagrant" - might have made it less likely that individuals engaged in bona fide humanitarian interventions would be prosecuted for the crime of aggression.

The United States succeeded in raising the threshold on the term "manifest" slightly with an Understanding that states:

It is understood that in establishing whether an act of aggression constitutes a manifest violation of the Charter of the United Nations, the three components of character, gravity and scale must be sufficient to justify a "manifest" determination. No one component can be significant enough to satisfy the manifest standard by itself.

Given the degree of variation in states' preferences, the term "manifest" remains ambiguous: to some, the word refers to the degree of legal clarity surrounding the state's conduct; to others, the word denotes some level of seriousness (in terms of the impugned act's scale or consequences) or wilfulness. The focus on "consequences" in the Understandings allows for an opening to argue that a military operation that may have violated Article 2(4) of the U.N. Charter as a technical matter might not be deemed to constitute an act of aggression by virtue of the

24) All the understandings appear in Annex II of Resolution RC/Res.6, supra note 17.

25) ICC Statute, supra note 4, Art. 1. 
fact that it ultimately improved the situation on the ground by protecting civilians and vulnerable groups from further attack.

\section{Purpose and Intent}

One avenue for creating an opening for humanitarian interventions that was not

fully explored would have been to tinker with the mens rea element of the crime of aggression with respect to the definition of the "crime of aggression". ${ }^{26}$ As it stands, the definition of "crime of aggression" contains a combination intention/ 215 knowledge-of-fact formulation: the defendant must intend to commit an enumerated act of aggression and must have knowledge of the factual circumstances that render the act a manifest violation of the Charter (e.g., the absence of Security Council authorisation or the absence of a prior attack by the putative victim state). The defendant need not, however, have knowledge of the applicable legal doctrine concerning the use of force. If drafters in Kampala had followed reasoning from some Nuremberg-era jurisprudence ${ }^{27}$ and required proof of a heightened mental state implying some illicit purpose behind the actions - such as a specific intent or motive element or some showing of bad faith, malice, wilfulness, or hostile intent - they might have provided a textual basis for distinguishing bona fide from pretextual humanitarian interventions. ${ }^{28}$

In the alternative, delegates could have added some notion of motive or intentionality to the definition of the state act of aggression, bearing in mind the difficulty of attributing an 'intention' to an artificial entity like a state. For example, the United States suggested that the Court be directed to consider the state's "purpose" for using force when determining whether an act of aggression had been committed, which would have provided a potential opening to argue for the legality of humanitarian interventions. Alternatively, along the lines of a prior but abandoned German proposal, "act of aggression" could have been defined with reference to the wilfulness or hostile intent behind a governmental policy. In the

\footnotetext{
26) See Elise Leclerc-Gagné and Michael Byers, 'A Question of Intent: The Crime of Aggression and Unilateral Humanitarian Intervention', 41 Case Western Reserve Journal of International Law (2009) 379.

27) In the High Command Case, the tribunal stated that the lawful or unlawful character of a war turns on its purpose: "Whether a war be lawful, or aggressive and therefore unlawful under international law, is and can be determined only from a consideration of factors that entered into its initiation. In the intent and purpose for which it is planned, prepared, initiated, and waged is to be found its lawfulness or unlawfulness." United States v. Von Leeb (The High Command Case), 11 Trials of War Criminals Before the Nuremberg Military Tribunals Under Control Council Law No. 10 (1949) pp. 462, 486.

28) See Andreas L. Paulus, 'Peace through Justice? The Future of the Crime of Aggression in a Time of Crisis', 50 Wayne Law Review (2004) 27 (noting requirement under German law that the defendant must possess the specific intent to disturb the peaceful coexistence of peoples).
} 
alternative, the definition could have listed a series of prohibited purposes, such as conquest, establishing a military occupation in the victim state, launching a war of aggression, achieving the annexation of the other state's territory, acquiring the other state's material resources, undermining the political independence of the state, or violating a state's neutrality. None of these proposals was adopted, and so the purpose behind a particular use of armed force can be considered only with reference to the terms character, gravity, and scale.

\section{Character, Gravity and Scale}

Under the provisions ultimately adopted, the only way for any party to address potentially unlawful but nonetheless legitimate uses of force is with reference to the tripartite factors of character, gravity, and scale. Drafters did not consider how these factors should be defined, leaving it to the Court for interpretation. Both gravity and scale, while not entirely synonymous, refer to the severity, magnitude, and consequences of a particular use of force. Indeed, both scale and character are arguably components of gravity that cannot really be assessed independently. The term "character", as a more qualitative term, is the most elastic of the three factors and might provide an opening to argue that an act of aggression was not committed with hostile intent or for aggressive purposes.

\section{Particularised Defences}

Finally, delegates could also have subjected the crime of aggression to special justifications or excuses. Negotiators did not, however, seriously consider amending the ICC Statute provisions addressing available defences. As it stands, individual defendants under indictment for the crime of aggression can invoke all of the existing defences - subject to whatever adaptations are necessary - set out in the ICC Statute. In particular, Article 31(1) provides that a defendant may be exonerated if he is acting in self-defence, in the defence of others, or under duress. Subparagraph $(1)(\mathrm{c})$ - the only provision that implicates the crime of aggression directly - states: "The fact that the person was involved in a defensive operation conducted by forces shall not in itself constitute a ground for excluding criminal responsibility under this subparagraph". Thus, neither self-defence nor the defence of others is automatically proven in situations in which the defendant is acting on behalf of a state engaged in self-defence, presumably within the terms of Article 51 of the U.N. Charter. ${ }^{29}$ Delegates could have added a provision to

29) This provision states: "The fact that the person was involved in a defensive operation conducted by forces shall not in itself constitute a ground for excluding criminal responsibility under this subparagraph". 
allow more clearly for a consideration of whether the state's use of force was motivated by the defence of others. Article 31 is addressed to individual defences and does not easily accommodate 'defences' that might be raised by the putative aggressor state at the stage in the proceedings at which the state act of aggression is under consideration. Indeed, it is unclear procedurally whether either the impugned state or the putative victim state will have standing to participate in the aggression determination absent amendment to the ICC Statute or Rules of Procedure. ${ }^{30}$

\section{Chilling Humanitarian Intervention in Theory and Practice}

It remains to be seen whether and how the adopted Understandings will impact on the travaux préparatoires or influence prosecutions before the Court in light of their uncertain legal authority. ${ }^{31}$ Some delegations supported the content or 280 impulse behind the rejected Understandings, but deemed them unnecessary or superfluous; others expressed concerns as to their very content. Many were sympathetic to the idea that humanitarian interventions should not be prosecuted as the crime of aggression, but preferred to grant the Court discretion in this regard. Given this ambiguous record, it will be for the various organs and constituencies of the ICC - including the Prosecutor exercising prosecutorial discretion and the Pre-Trial Division filter - to determine how to address future humanitarian interventions. By virtue of this delegation of interpretive authority, the ICC is thus poised to play a role as arbiter on the legality of humanitarian interventions. The variety of meanings of the term 'manifest' coupled with the nuances contained in the Understandings provide tentative grounds for bona fide humanitarian interventions to avoid scrutiny by the Court under the rubric of the crime of aggression.

Nonetheless, because the crime is expansively and ambiguously defined, the potential exists for the new aggression provisions to chill arguably beneficent uses of force that lack Security Council approval, such as: multilateral, regional, or unilateral peacekeeping missions and humanitarian interventions; rescue operations;

\footnotetext{
30) See Beth Van Schaack, 'Question on the ICC Aggression Filter', IntLawGrrls, 24 July 2010, <intlawgrrls.blogspot.com/2010/07/question-on-icc-aggression-filter.html>, (discussing lack of standing of states during the aggression determination); See International Criminal Court, Rules of Procedure and Evidence of the International Criminal Court (U.N. Doc. PCNICC/2000/1/Add.1) (2000).

31) See Kevin Jon Heller, 'Are the Understandings Valid?', Opinio Juris, <opiniojuris.org/2010/06/16/ are-the-aggression-understandings-valid/>, (arguing that the seven understandings adopted at the review conference should be ignored by the judges); Kevin Jon Heller, 'Marko Milanovic on Understandings', Opinio Juris, <opiniojuris.org/2010/06/16/marko-milanovic-on-understand ings/>, (arguing that the Court must consider the understandings as part of the interpretive framework for the treaty).
} 
or even (more controversially) military responses to acts of terrorism that might incapacitate terrorist organisations and prevent future attacks. Humanitarian interventions may be more susceptible to being chilled than other uses of force of ambiguous legality. Bona fide humanitarian interventions are discretionary and often do not directly implicate sovereign prerogatives as do actions compelled by an extension of a right of self-defence. The risk of chilling the exercise of such an 'imperfect duty', if it can even be called that, is thus greater. ${ }^{32}$ Indeed, even in the face of a horrific genocide, the international community found a host of excuses for not intervening more robustly in Rwanda. The codification of a crime of aggression without any humanitarian exception provides one more excuse for inaction in the face of atrocities. To be sure, creating a penal forum to judge uses of force may discourage states from undertaking pre-textual humanitarian interventions. At the same time, the way in which the crime of aggression as been codified might also derail creative thinking geared toward establishing universal standards and designing institutions to manage interventions and protect against abuses. ${ }^{33}$ The international community must continue its work on the responsibility to protect doctrine with an eye toward establishing standards that the Court can employ in making the predicate aggression determination in the face of arguably humanitarian uses of force.

\section{Intervening on Behalf of Women}

For those of us concerned about augmenting international law's ability to protect women, should we care about over-deterring humanitarian interventions and other uses of force that do not constitute an a hostile attack or rise to the level of aggressive war? It is unlikely that feminist thinkers will ever universally come to terms with the idea of a just war. ${ }^{34}$ To be sure, many feminists have fought for more robust forms of intervention in conflict zones where women were at risk. ${ }^{35}$ These calls intensified when the Taliban began imposing a form of gender apartheid in Afghanistan. ${ }^{36}$ It took the attacks of September 11 th, however, for the

\footnotetext{
32) See Gary Banham, Kant's Practical Philosophy: From Critique to Doctrine (Palgrave Macmillan, 2006) pp. 186-198 (discussing Kant's notion of an imperfect duty).

33) See Allen Buchanan and Robert O. Keohane, 'The Preventive Use of Force: A Cosmopolitan Institutional Proposal', 18 Ethics \& International Affairs (2004) 1 (proposing the establishment of a council of democratic states to vet proposed interventions).

34) Of course, the feminist perspective on many areas of law is neither static nor monolithic; rather, it is multifaceted and is constantly evolving. See Lucinda Peach, 'An Alternative to Pacifism? Feminism and Just-War Theory', 9 Hypatia (1994) 152.

35) See Catharine A. MacKinnon, 'Women's September $11^{\text {th }}$ : Rethinking the International Law of Conflict', 47 Harvard International Law Journal (2006) 1.

36) See, e.g., Feminist Majority Foundation, Stop Gender Apartheid in Afghanistan, <www .helpafghanwomen.com/Global_Petition_Flyer.pdfs.
} 
United States to mobilise Operation Enduring Freedom in Afghanistan. Although the plight of women under the Taliban was not a prime motivator for the intervention, the rhetoric surrounding the intervention appropriated feminist concerns about the quality of women's lives under Taliban rule to garner the support of domestic and international constituencies for the Operation. ${ }^{37}$ Indeed, the propaganda value of violence against women has long been recognised. ${ }^{38}$ To date, preventing harm to women has served only as a convenient makeweight argument in the service of interventions initiated for other rationales. ${ }^{39}$

To be sure, interventions have been launched or considered in situations that have featured grave violations of women's rights. That said, interventions that did go forward have not necessarily benefited women across the board. It is now clear that women in Afghanistan have not necessarily fared better following the partial ouster of the Taliban. ${ }^{40}$ Nor were the women of Kuwait liberated along with their country by Operation Desert Storm. ${ }^{41}$ Even in Kosovo, where NATO's intervention halted an ethnic cleansing, the introduction of foreign troops occasioned a dramatic increase in sex trafficking and forced prostitution. ${ }^{42}$

\footnotetext{
37) Ann Russo, 'The Feminist Majority Foundations Campaign to Stop Gender Apartheid: Intersections of Feminism and Imperialism in the United States', 8 International Feminist Journal of Politics (2006) 557, <www2.hawaii.edu/-dasgupta/RussoFMF.pdf>, (arguing that the Feminist Majority Foundation was complicit in the Bush Administration's appropriation of feminist ideas to justify interventions).

38) Susan Brownmiller, Against Our Will: Men, Women and Rape (Fawcett Books, New York, 1975) pp. $40-48$.

39) The plight of women has also been employed to justify keeping troops in Afghanistan. See Aryn Baker, 'What Happens If We Leave Afghanistan', TIME, 9 August 2010. The magazine has been criticised for cynically using violence against women as propaganda in support of the continued engagement in Afghanistan and presenting a falsely dichotomous dilemma-women remain safe if the foreign troops stay on or women are left to be mutilated if the troops leave. See Derrick Crow, 'TIME's Epic Distortion of the Plight of Women in Afghanistan', Rethinking Afghanistan, 31 July 2010, <rethinkafghanistan.com/blog/2010/07/times-epic-distortion-of-the-plight-of -women-in-afghanistan/>.

40) See Human Rights Watch, 'The "Ten-Dollar Talib” and Women's Rights', 13 July 2010, pp. 6, 21, <www.hrw.org/sites/default/files/reports/afghanistan0710webwcover.pdf>, (arguing that "far from ensuring that the rights of women are respected, the current Afghan government has regularly sold them short" and that women have few opportunities to assert their rights in today's Afghanistan because "powerful factions in the government and parliament ... are opposed to many of the rights and freedoms that women now enjoy.").

41) See Amnesty International, 'Gulf Cooperation Council (GCC) Countries: Women Deserve Dignity and Respect', <www.amnestyusa.org/document.php?id=DAC1E87CECCA7C1780256F CE00586B83\&lang=e $>$. Women in Iraq remained subjugated as well. See Foreign \& Commonwealth Office, 'Saddam Hussein: Crimes and Human Rights Abuses', November 2002, pp. 8-9, <image .guardian.co.uk/sys-files/Guardian/documents/2002/12/02/hrdossierenglish.pdf>, (detailing abuses against women after the first Gulf War).

42) Samantha Godec, 'Between Rhetoric and Reality: Exploring the Impact of Military Humanitarian Intervention Upon Sexual Violence - Post-Conflict Sex Trafficking in Kosovo', 92 International Review of the Red Cross (2010) 245-247.
} 
Many strains of feminism - whether based on an affirmative essentialism borne of biological reductionism or premised on theories of differential socialisation and social constructivism - are closely tied to pacifism in rejecting the masculinist impulse to resort to arms in the face of conflict. ${ }^{43}$ The temptation to invoke armed intervention in the face of atrocities may limit the ability of the international community to imagine, design, and implement other non-violent forms of conflict resolution. ${ }^{44}$ While ostensibly protective, humanitarian interventions threaten more violence, at least in the short term (if not longer). ${ }^{45}$ Such operations valorise militarism and entail the deployment of armed force capable of causing great destruction, injuring civilians, and devastating societies. Doing so in the name of humanitarianism or even in the defence of women does not negate the harm caused to civilians who become collateral damage or are violently displaced. The idea of humanitarian intervention in defence of women also furthers the vulnerable victim narrative by portraying women as in need of a heroic male saviour. ${ }^{46}$ That said, anyone who is the innocent victim of violence deserves to be rescued from her predicament, and encouraging women to exercise their autonomy and agency is simply folly when they are looking down the barrel of a gun. ${ }^{47}$

43) Betty Reardon, Sexism and the War System (1985) (portraying women as inherently peaceful and anti-militaristic); Mary Caprioli, 'Gendered Conflict', 37 Journal of Peace Research (2000) 51 (positing with data that domestic gender equality has a pacifying effect on state foreign policy decisions). But see Hilary Charlesworth, 'Are Women Peaceful? Reflections on the Role of Women in PeaceBuilding', 16 Feminist Legal Studies (2008) 347, 349, 359 (citing authorities that challenge the link between feminism and pacifism); Carolyn M. Stephenson, 'Feminism, Pacifism, Nationalism, and the United Nations Decade for Women', 5 Women's Studies International Forum (1982) 5-6 (critiquing the determinative linkage between women and peace).

44) See Strategic Objective E.3, Beijing Declaration and Platform for Action, Fourth World Conference on Women, (U.N. Doc. A/CONF.177/20) (1995) and (A/CONF.177/20/Add.1) (15 September 1995) (calling on the international community to "[p] romote non-violent forms of conflict resolution and reduce the incidence of human rights abuse in conflict situations."); Sara Ruddick, Maternal Thinking Towards a Politics of Peace (1995) pp. 141-159; ibid., xviii-xx (discussing potential for nonviolent action in the face of atrocities).

45) Karen Engle, "'Calling in the Troops": The Uneasy Relationship Among Women's Rights, Human Rights, and Humanitarian Intervention', 20 Harvard Human Rights Journal (2007) 189 ("I am uneasy with the idea that destroying life and infrastructure is a way to demonstrate concern for a particular place or situation, especially when most of history has shown that such intervention-regardless of motivation-rarely improves the lives of the individuals who are the stated subjects of intervention.”).

46) Godec, supra note 42 (arguing that "saving women" narratives "are regressive for women's rights."). This attitude appears in an orientalist or neo-colonialist form where western troops are portrayed as rescuing women from barbaric practices. See Faiza Hirji, The War for Women's Freedom: Orientalist Imaginaries of Rescue in Afghanistan (2005), <www.allacademic.com/meta/p_mla_apa _research_citation/0/1/4/7/9/p14796_index.html>.

47) Christine M. Chinkin, 'Kosovo: A “Good” or "Bad” War?', 93 American Journal of International Law (1999) 843 (observing, "How can I, as an advocate of human rights, resist the assertion of a moral imperative on states to intervene in the internal affairs of another state where there is evidence of ethnic cleansing, rape and other forms of systematic and widespread abuse, regardless of what the Charter mandates about the use of force and its allocation of competence?"). 
Despite these concerns with part practice, it is possible to envision a beneficial humanitarian intervention on behalf of women. Ancient ${ }^{48}$ and modern just war theories suggest some elements that would be required for any valid intervention. ${ }^{49}$ Factors often mentioned include: action by a legitimate authority; pursuit of a right intention (the advancement of good or the avoidance of evil); abuses that exceed some gravity threshold; the use of force as a last resort after efforts at diplomacy, negotiation and other sanctions had failed; a proportional response; and a reasonable prospect of success. In terms of legitimate power, a prioritising of Security Council action, or at a minimum multilateral or regional action, is a central feature of modern theorising about humanitarian intervention. And yet, uncertainties surrounding the definition of the crime of aggression, coupled with the checkerboard jurisdictional regime, will no doubt impede coalition-building, adherence to military alliances, and other multilateral responses to global threats. The unequal threat of prosecution among states may give rise to differential tolerances for the degree of uncertainty inherent to the reach of the aggression amendments. The concomitant difficulty in mobilising joint action may paradoxically lead to more unilateral actions by states not subject to the aggression amendments ${ }^{50}$ or the moderating effects of joint action. Thus, the existence of the crime on the books may ultimately make multilateral action more difficult.

An additional requirement would be that such an intervention would result in the diminution rather than escalation of violence. Although humanitarian interventions involve armed force, one can surmise that parties engaged in just wars might ultimately produce less collateral damage than those engaged in aggressive wars due to the fact that combatants and their commanders are likely to assign different values to the variables employed in the proportionality calculus (military utility and the risk of collateral harm) than their hostile adversaries. These variables are elastic by design and provide a certain degree of latitude to combatants to implement military strategy. Arguably, those involved in non-hostile uses of force might demand a greater degree of military necessity to justify a course of conduct or tolerate less potential for collateral harm in choosing their targets. ${ }^{51}$ Indeed, at the risk of melding the jus in bello and the jus ad bellum, an argument could be made that combatants engaged in a humanitarian intervention should

\footnotetext{
48) See Larry May, et al., The Morality of War: Classical and Contemporary Readings (Perason, 2006) 110 (compiling just war theories through the ages).

49) See ICISS, The Responsibility to Protect, supra note 6.

50) The nationals of non-party states and states that opt out of the aggression provisions cannot be prosecuted for the crime. Resolution RC/Res.6, supra note 17, Art. 15bis(4)-(5).

51) But see Final Report to the Prosecutor by the Committee Established to Review the NATO Bombing Campaign Against the Federal Republic of Yugoslavia, <www.icty.org/x/file/About/OTP/otp_report _nato_bombing_en.pdf>, (discussing potential war crimes committed during Kosovo intervention, but declining to go forward with prosecutions).
} 
be subject to heightened duties under humanitarian law in light of their ulterior protective purposes..$^{52}$

It is difficult to construct a feminist framework for humanitarian intervention on behalf of women under contemporary conditions, when women are so often excluded from decisions about uses of force. ${ }^{53}$ Humanitarian intervention may be more palatable to feminists, and ultimately more beneficial to women, when women are included in decision-making surrounding the propriety of military intervention, ${ }^{54}$ as opposed to other responses, ${ }^{55}$ as well as in the design and implementation of such operations. ${ }^{56}$ Security Council Resolution 1325 - the first thematic resolution on women, peace and security - recognised the potential for women to be peacemakers and reaffirmed the importance of their "equal participation and full involvement in all efforts for the maintenance and promotion of peace and security, and the need to increase their role in decision-making with regard to conflict prevention and resolution". ${ }^{57}$ Resolution 1820 , which supplements 1325, focuses on sexual violence and signals the Council's "readiness" to "adopt appropriate steps to address widespread or systemic sexual violence". These landmark resolutions indicate that such abuses fall within the Council's jurisdiction as threats to international peace and security ${ }^{58}$ and have the potential to surpass any gravity threshold required for humanitarian action. The resolutions thus provide a theoretical platform with a Security Council imprimatur to integrate women and women's groups into decision-making about the propriety and execution of humanitarian intervention. ${ }^{59}$ That said, empirical evidence suggests that Resolution 1325 has exerted only a modest impact on peace processes

52) Ruti Teitel, 'The Wages of Just War', 39 Cornell International Law Journal (2006) 695.

53) Chinkin, supra note 1, p. 279 ("The reality of who is making those decisions [on behalf of the state] and the effect of those decisions upon individuals within States may well take on a different perspective when examined from a gendered viewpoint.").

54) Helen Stacy, 'Humanitarian Intervention and Relational Sovereignty', in Stephen Lee (ed.), Intervention, Terrorism, and Torture (2006), <www.stanford.edu/group/sjir/7.1.06_stacy.html>, (arguing that the consensus of at-risk citizens should be assured before any intervention is launched). 55) Christine Chinkin, Peace Agreements as a Means for Promoting Gender Equality and Ensuring Participation of Women, United Nations Division for the Advancement of Women Expert Group Meeting (13 November 2003) p. 10, <www.peacewomen.org/assets/file/Resources/Academic/Part _PeaceAgrmentsGndrEqual_ChinkinLSE_2003.pdf> (noting that the "[f]ailure to include [women's] views and ideas can lead to an impoverished understanding of peace and security that focuses on militarism and power supported by force.").

56) Peach, supra note 34 (noting that women are absent from legal and ethical inquiries about war). 57) U.N. Security Council Resolution 1325 (U.N. Doc. S/RES/1325) p. 1 (31 October 2000).

58) U.N. Security Council Resolution 1820 (U.N. Doc. S/RES/1820) para. 1 (19 June 2008). A subsequent resolution noted the perennial under-representation of women in formal peace processes notwithstanding the mandate for women's greater inclusion set forth in Resolution 1325. U.N. Security Council Resolution 1960 (U.N. Doc. S/RES/1960) p. 1 (19 June 2008).

59) See Alain-Guy Tachou-Sipowo, 'The Security Council on Women in War: Between Peacebuilding and Humanitarian Protection', 92 International Review of the Red Cross (2010) 197. 
to date and that much remains to be done to fully integrate women into decision making about how to manage armed conflicts. ${ }^{60}$

\section{Conclusion}

If we care about what happens to women in war, we should do everything in our 417 power to decrease the incidence of war in the first place. It is too early to tell whether the inclusion of the crime of aggression in the ICC Statute will be able to do this. Once again, we find ourselves in a reactive posture asking the 'woman question', which entails exploring the gender implications of the law ${ }^{61}$ and engaging in a continuing task of determining how legal doctrines and institutions which women played little hand in constructing - affect women. ${ }^{62}$ It is possible at this stage, however, to anticipate the impact that the new provisions may have on the nascent doctrine of responsibility to protect. This article should not be read as a ringing endorsement of humanitarian intervention, as we must remain vigilant about "the dark sides of virtue". ${ }^{63}$ The codification of a broad crime of aggression, with few openings to argue for the legality or legitimacy of uses of force for humanitarian purposes, certainly complicates this vital process of doctrinal development. Nonetheless, exigent threats to women's rights remain. This sad truth justifies our continual work toward developing a normative and procedural framework that will allow bona fide humanitarian interventions to proceed without threat of prosecution for the crime of aggression.

60) See Christine Bell and Catherine O'Rourke, 'Peace Agreements or Pieces of Paper? The Impact of the UNSC Resolution 1325 on Peace Processes and Their Agreements', 59 International and Comparative Law Quarterly (2010) 941 (noting a slight increase in references to women in peace processes since the passage of Resolution 1325, especially in situations in which the United Nations is involved).

61) See Katharine T. Bartlett, 'Feminist Legal Methods', 103 Harvard Law Review (1990) 829, 836, 837 (advocating that feminists ask "the woman question" both to "expose how the substance of law may silently and without justification submerge the perspectives of women and other excluded groups" and to "identify the gender implications of rules and practices which might otherwise appear to be neutral or objective.").

62) Doris Buss, 'Is International Criminal Law Feminist?', in Cecilia M. Bailliet (ed.), The Creation of International Law: An Exploration of Normative Innovation, Contextual Application, and Interpretation in a Time of Flux (2010) ("When faced with an existing institutional apparatus ... feminist advocates often do not have the luxury of opting out. The realm of legal and political work for feminists has, to a degree, already been defined."). See also, in this special issue, Doris Buss, 'Is International Criminal Law Feminist?', (11)3 International Criminal Law Review (2011) 409-423. 63) David Kennedy, The Dark Sides of Virtue: Reassessing International Humanitarianism (Princeton University Press, Priceton, 2004). 
